CARDIOVASCULAR MEDICINE

\title{
Variation during the week in the incidence of acute myocardial infarction: increased risk for Japanese women on Saturdays
}

\author{
K Kinjo, H Sato, H Sato, I Shiotani, T Kurotobi, Y Ohnishi, E Hishida, D Nakatani, \\ H Mizuno, Y Yamada, S Fukui, M Fukunami, S Nanto, Y Matsu-ura, H Takeda, M Hori, \\ on behalf of the Osaka Acute Coronary Insufficiency Study (OACIS) Group*
}

Heart 2003;89:398-403

See end of article for authors' affiliations

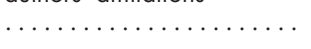

Correspondence to: Dr Hiroshi Sato,

Department of Internal Medicine and

Therapeutics, Osaka

University Graduate School

of Medicine, 2-2

Yamadaoka, Suita, Osaka

565-0871, Japan;

satoz@

medone.med.osaka-u.ac.jp

${ }^{*}$ A full list of participating centres and physicians is given in the appendix.

Accepted

20 November 2002
Background: Variations in the incidence of acute myocardial infarction during the week may differ between and within communities, according to lifestyle.

Objective: To identify potential triggering factors for acute myocardial infarction by examining variations in incidence in the days of the week within the Osaka area of Japan.

Patients: Of 2511 consecutive patients in this region who were admitted to hospital for acute myocardial infarction between April 1998 and March 2001 and consented to take part, 2400 who had a definitely identified time of onset were enrolled.

Results: For this group as a whole, no significant difference in incidence was noted between days of the week. However, in subgroup analyses women were shown to have significant variation through the week, peaking on Saturday with a 39\% increase in relative risk ( $p=0.037)$; working subjects showed a peak on Monday, with a $26 \%$ increase in relative risk $(p=0.038)$. Stratified analyses showed that in working men there was a prominent Monday peak in the onset of infarction, with a $30 \%$ increase in relative risk $(p=0.022)$, while in working women, there was no significant variation through the week. Conclusions: Earlier findings of a Monday peak linked to increased physical and mental occupational stress are confirmed. There is also an increase in uncertain risk factors on Saturdays for Japanese women, possibly involving a stressful weekend burden for women. Confirmation of this finding in other communities may help identify triggers of acute myocardial infarction and be useful in prevention.
$\mathrm{P}$ revious studies on weekly variation in the onset of acute myocardial infarction have been inconsistent. ${ }^{1-7}$ However, most investigators ${ }^{1-5}$ have found an increased risk on Mondays, probably reflecting the physical and mental stress of return to work after the weekend. ${ }^{3}$ Thus external stimuli may act as triggers in subjects with coronary artery disease. ${ }^{8}$

Occupational stress is not the only trigger of the onset of myocardial infarction; certain other external stresses including physical activity, mental stress, sexual activity, natural disasters such as earthquakes or blizzards, and warfare have been found to increase cardiac events. ${ }^{9-13}$ Specific stresses are likely to differ in importance as triggers between individuals and communities. Family life and leisure patterns at weekends may lead to mental stress and frustration, as noted in women with weekend headaches. ${ }^{14}$ While lifestyles in Japan have been rapidly westernised, major differences between western countries and Japan remain. Both the patterns of stress in daily life and the variation in onset of myocardial infarction during the week may differ between cultures. To test this possibility, we examined the patterns of onset of acute myocardial infarction during the week, using a myocardial infarction registry-the Osaka acute coronary insufficiency study (OACIS) - which is established in the Osaka area in Japan. To identify potential triggering factors for myocardial infarction, we undertook subgroup analyses involving relevant demographic variables.

\section{METHODS}

\section{Purpose of the registry}

A detailed description of OACIS has been published elsewhere. ${ }^{15}{ }^{16}$ It is a prospective multicentre observational study in which 25 collaborating hospitals in the Osaka area of Japan record demographic, procedural, and outcome data and collect blood samples from patients with acute myocardial infarction. The purposes of this registry are twofold: to collect uniform prospective data on patients with acute myocardial infarction which can be used to assess clinical variables, therapeutic procedures, and clinical events; and to collect samples of genomic DNA on affected individuals which can be used to investigate whether common variants in the human genetic background are associated with the pathogenesis of acute myocardial infarction. The study protocol was approved by each hospital's ethics committee.

\section{Definitions}

The diagnosis of acute myocardial infarction required the presence of two of the following three criteria:

- a clinical history of central chest pressure, pain, or tightness lasting for 30 minutes or more

- typical ECG changes: ST segment elevation of more than $0.1 \mathrm{mV}$ in at least one limb or two precordial leads, ST segment depression greater than $0.1 \mathrm{mV}$ in at least two leads, an abnormal Q wave, or $\mathrm{T}$ wave inversion in at least two leads

- an increase in serum creatine kinase concentration to more than twice the normal laboratory value.

The time of onset was defined as the onset of the acute symptoms of the coronary event. When the patient had vague intermittent symptoms followed by prolonged symptoms, the onset would be that of the prolonged symptoms. All patients presenting within one week after the onset of acute myocardial infarction were registered prospectively. Collaborating hospitals were encouraged to enter consecutive patients with acute myocardial infarction, irrespective of treatment strategy and outcome. 


\begin{tabular}{|c|c|}
\hline Variables & $\begin{array}{l}\text { Number }(\%) \text { of } \\
\text { patients }\end{array}$ \\
\hline All subjects & $2400(100)$ \\
\hline \multicolumn{2}{|l|}{ Sociodemographic variables } \\
\hline Men & $1796(74.8)$ \\
\hline Women & $604(25.2)$ \\
\hline \multicolumn{2}{|l|}{ Age } \\
\hline$\geqslant 65$ years & $1248(52.0)$ \\
\hline$<65$ years & $1152(48.0)$ \\
\hline Working & $1247(54.6)$ \\
\hline \multicolumn{2}{|l|}{ Habits } \\
\hline Current cigarette smoking & $1226(54.0)$ \\
\hline Habitual alcohol drinking & $664(29.9)$ \\
\hline \multicolumn{2}{|l|}{ Medical history } \\
\hline Diabetes mellitus & $791(34.0)$ \\
\hline Hypertension & $1156(50.2)$ \\
\hline Hyperlipidaemia & $878(39.0)$ \\
\hline Previous myocardial infarction & $317(14.1)$ \\
\hline Previous angina pectoris & $638(28.6)$ \\
\hline \multicolumn{2}{|l|}{ Infarct characteristics } \\
\hline$Q$ wave infarction & $1726(75.5)$ \\
\hline Anterior infarction & $1169(51.3)$ \\
\hline Multivessel disease & $641(29.9)^{*}$ \\
\hline
\end{tabular}

\section{Data collection and quality control}

Research cardiologists and specialised research nurses recorded data on sociodemographic variables, medical history, therapeutic procedures, and clinical events. After written informed consent for taking part in the OACIS was obtained from the patient, all hospital data were transmitted to the OACIS office.

Before initiation of the study, research cardiologists and specialised research nurses received a training manual. Double key entry was used to add each case report form to the database. Audits were performed electronically to detect out of range variables, inconsistencies, errors, or omissions. Queries were then telephoned to local research cardiologists and specialised research nurses for resolution.

\section{Patients}

In all, 2511 consecutive patients were registered in the OACIS from April 1998 to March 2001. The day of the onset of acute myocardial infarction was determined by the attending physician as the day on which the typical symptoms first occurred, and not the day of presentation to a physician. Among the 2511 patients, the day of onset could not be definitely identified in 31 cases because of absence of typical chest pain or for various other reasons. As the purpose of the study was to explore environmental triggers of the onset of acute myocardial infarction in the community, we also excluded a further 80 patients whose infarction occurred while they were in hospital for evaluation or treatment of other diseases. Thus the final cohort comprised 2400 patients.

\section{Data analysis}

Subgroups of patients were formed on the basis of 13 variables listed in table 1 . These variables were selected a priori for subgroup analysis to confirm the results of previous studies or because they were considered likely to affect the physiological status of the subject and thereby potentially affect the weekly variation in the onset of acute myocardial infarction. Because coronary angiography was undertaken in 2146 of the patients $(89.4 \%)$, subgroup analysis with respect to the number of diseased vessel was also done in those patients.

Working subjects were persons who satisfied one of the following two conditions: either they were hired for an indefinite

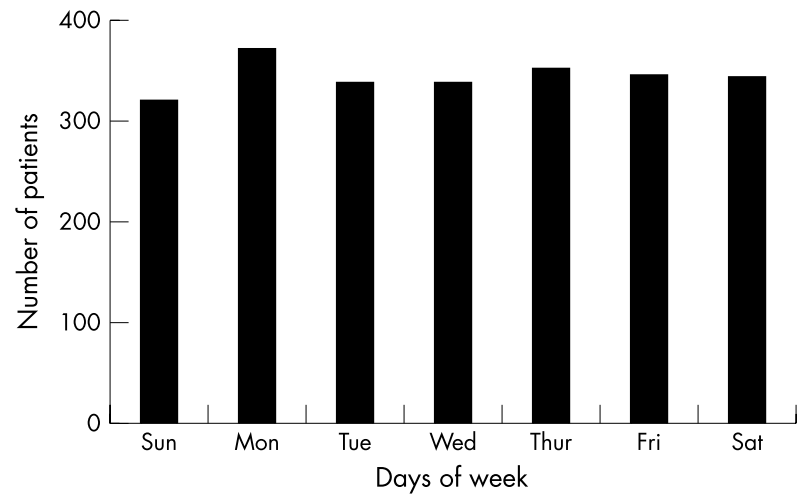

Figure 1 Day of the week of acute myocardial infarction for all subjects $(n=2400)$. The number of cases was largest on Monday, but the Mantel-Haenszel test indicated that an excess relative risk of onset on Monday was not significant (odds ratio 1.09, $95 \% \mathrm{Cl} 0.93$ to $1.28 ; p=0.292$ )

period longer than one month, or they were hired by the day or for less than one month but had been working for 18 days or more in each of the two months preceding the infarct. Though a full time housewife is a worker and may be described as "not working outside the home," for the purposes of this study a full time housewife was classified as being in the non-working population.

Diabetes mellitus was defined as a fasting plasma glucose of $\geqslant 7 \mathrm{mmol} / \mathrm{l}(126 \mathrm{mg} / \mathrm{dl})$, or the use of antidiabetic treatment. A documented previous systolic blood pressure of $\geqslant 140 \mathrm{~mm} \mathrm{Hg}$, a diastolic blood pressure of $\geqslant 90 \mathrm{~mm} \mathrm{Hg}$, or the use of antihypertensive drug treatment defined a history of hypertension. A documented previous fasting total cholesterol concentration of $\geqslant 5.7 \mathrm{mmol} / \mathrm{l}(220 \mathrm{mg} / \mathrm{dl})$, or a fasting triglyceride concentration of $\geqslant 1.7 \mathrm{mmol} / \mathrm{l}(150 \mathrm{mg} / \mathrm{dl})$, or antilipidaemic treatment defined a history of hyperlipidaemia. Hospital records and ECGs were examined to corroborate a history of infarction. A history of angina pectoris was diagnosed when substernal distress of short duration was related to exertion or excitement and relieved by rest or glyceryl trinitrate. Patients were considered to be current cigarette smokers if they regularly used cigarettes. Habitual alcohol intake was defined by consumption of two drinks or more a week.

\section{Statistical analysis}

We used $\chi^{2}$ goodness of fit tests, including Bonferroni correction for multiple testing, to assess the uniformity of myocardial infarction onset with respect to the day of the week. An excess relative risk of cardiac events on individual days of the week was calculated by age adjusted MantelHaenszel statistics. ${ }^{17}$ Stratified analysis and multivariate logistic regression models were used to assess the contribution of sociodemographic and medical factors to the weekly distribution of cardiac events. For all analyses, significance was defined as a probability value of $\mathrm{p}<0.05$.

\section{RESULTS}

\section{Day of onset of acute myocardial infarction}

The characteristics of 2400 patients who were enrolled in this study are shown in table 1.

The number of patients with myocardial infarction was largest on Monday and smallest on Sunday (fig 1). However, the distribution of the day of onset during the week for all subjects showed no significant variation $\left(\chi^{2}\right.$ test, $\left.p=0.678\right)$, indicating that the distribution was fairly random in our community as a whole.

\section{Subgroup analysis and day of onset}

The distribution of the onset of myocardial infarction by day of the week was examined in subgroups of patients categorised 
Table 2 Weekly distribution of the onset of acute myocardial infarction in patient subgroups, categorised by sociodemographic variables, medical history, habits, and infarct characteristics

\begin{tabular}{|c|c|c|c|c|c|c|c|c|}
\hline & \multicolumn{7}{|c|}{ Odds ratios ( $95 \%$ confidence interval) } & \multirow{2}{*}{$\begin{array}{l}\text { Total } \\
\text { (n) }\end{array}$} \\
\hline & Sunday & Monday & Tuesday & Wednesday & Thursday & Friday & Saturday & \\
\hline All subjects & $\begin{array}{l}0.92 \\
(0.78 \text { to } 1.08)\end{array}$ & $\begin{array}{l}1.09 \\
(0.93 \text { to } 1.28)\end{array}$ & $\begin{array}{l}0.98 \\
(0.83 \text { to } 1.15)\end{array}$ & $\begin{array}{l}0.98 \\
(0.83 \text { to } 1.15)\end{array}$ & $\begin{array}{l}1.02 \\
(0.87 \text { to } 1.20)\end{array}$ & $\begin{array}{l}1.00 \\
(0.85 \text { to } 1.17)\end{array}$ & $\begin{array}{l}0.99 \\
(0.85 \text { to } 1.17)\end{array}$ & 2400 \\
\hline \multicolumn{9}{|c|}{ Sociodemographic variables } \\
\hline Men & $\begin{array}{l}0.95 \\
(0.78 \text { to } 1.14)\end{array}$ & $\begin{array}{l}1.11 \\
(0.93 \text { to } 1.34)\end{array}$ & $\begin{array}{l}0.99 \\
(0.82 \text { to } 1.20)\end{array}$ & $\begin{array}{l}0.99 \\
(0.82 \text { to } 1.19)\end{array}$ & $\begin{array}{l}1.03 \\
(0.86 \text { to } 1.24)\end{array}$ & $\begin{array}{l}1.08 \\
(0.90 \text { to } 1.30)\end{array}$ & $\begin{array}{l}0.88 \\
(0.73 \text { to } 1.07)\end{array}$ & 1796 \\
\hline Women & $\begin{array}{l}0.87 \\
(0.62 \text { to } 1.21)\end{array}$ & $\begin{array}{l}1.06 \\
(0.77 \text { to } 1.45)\end{array}$ & $\begin{array}{l}0.96 \\
(0.69 \text { to } 1.33)\end{array}$ & $\begin{array}{l}0.99 \\
(0.71 \text { to } 1.36)\end{array}$ & $\begin{array}{l}1.01 \\
(0.74 \text { to } 1.40)\end{array}$ & $\begin{array}{l}0.79 \\
(0.56 \text { to } 1.11)\end{array}$ & $\begin{array}{l}1.39 * \\
(1.02 \text { to } 1.88)\end{array}$ & 604 \\
\hline \multicolumn{9}{|l|}{ Age (years) } \\
\hline$\geqslant 65$ & $\begin{array}{l}0.94 \\
(0.75 \text { to } 1.18)\end{array}$ & $\begin{array}{l}1.09 \\
(0.88 \text { to } 1.36)\end{array}$ & $\begin{array}{l}0.89 \\
(0.71 \text { to } 1.12)\end{array}$ & $\begin{array}{l}1.09 \\
(0.88 \text { to } 1.36)\end{array}$ & $\begin{array}{l}0.97 \\
(0.78 \text { to } 1.22)\end{array}$ & $\begin{array}{l}1.00 \\
(0.80 \text { to } 1.25)\end{array}$ & $\begin{array}{l}0.98 \\
(0.78 \text { to } 1.23)\end{array}$ & 1248 \\
\hline$<65$ & $\begin{array}{l}0.90 \\
(0.71 \text { to } 1.14)\end{array}$ & $\begin{array}{l}1.09 \\
(0.86 \text { to } 1.37)\end{array}$ & $\begin{array}{l}1.07 \\
(0.85 \text { to } 1.35)\end{array}$ & $\begin{array}{l}0.86 \\
(0.68 \text { to } 1.10)\end{array}$ & $\begin{array}{l}1.07 \\
(0.85 \text { to } 1.35)\end{array}$ & $\begin{array}{l}0.99 \\
(0.79 \text { to } 1.25)\end{array}$ & $\begin{array}{l}1.01 \\
(0.80 \text { to } 1.27)\end{array}$ & 1152 \\
\hline Working & $\begin{array}{l}0.89 \\
(0.71 \text { to } 1.12)\end{array}$ & $\begin{array}{l}1.26 \dagger \\
(1.01 \text { to } 1.56)\end{array}$ & $\begin{array}{l}1.03 \\
(0.82 \text { to } 1.28)\end{array}$ & $\begin{array}{l}0.92 \\
(0.73 \text { to } 1.15)\end{array}$ & $\begin{array}{l}1.05 \\
(0.84 \text { to } 1.31)\end{array}$ & $\begin{array}{l}0.97 \\
(0.78 \text { to } 1.22)\end{array}$ & $\begin{array}{l}0.87 \\
(0.69 \text { to } 1.09)\end{array}$ & 1247 \\
\hline Non-working & $\begin{array}{l}0.95 \\
(0.74 \text { to } 1.22)\end{array}$ & $\begin{array}{l}0.95 \\
(0.74 \text { to } 1.22)\end{array}$ & $\begin{array}{l}0.98 \\
(0.76 \text { to } 1.25)\end{array}$ & $\begin{array}{l}1.03 \\
(0.81 \text { to } 1.32)\end{array}$ & $\begin{array}{l}1.00 \\
(0.78 \text { to } 1.28)\end{array}$ & $\begin{array}{l}1.00 \\
(0.78 \text { to } 1.28)\end{array}$ & $\begin{array}{l}1.10 \\
(0.87 \text { to } 1.41)\end{array}$ & 1038 \\
\hline \multicolumn{9}{|l|}{ Habits } \\
\hline Current smoker & $\begin{array}{l}0.88 \\
(0.69 \text { to } 1.10)\end{array}$ & $\begin{array}{l}1.07 \\
(0.85 \text { to } 1.34)\end{array}$ & $\begin{array}{l}1.08 \\
(0.87 \text { to } 1.35)\end{array}$ & $\begin{array}{l}1.05 \\
(0.84 \text { to } 1.31)\end{array}$ & $\begin{array}{l}0.99 \\
(0.79 \text { to } 1.25)\end{array}$ & $\begin{array}{l}1.03 \\
(0.82 \text { to } 1.29)\end{array}$ & $\begin{array}{l}0.92 \\
(0.73 \text { to } 1.16)\end{array}$ & 1226 \\
\hline Not current smoker & $\begin{array}{l}0.94 \\
(0.73 \text { to } 1.20)\end{array}$ & $\begin{array}{l}1.14 \\
(0.89 \text { to } 1.44)\end{array}$ & $\begin{array}{l}0.90 \\
(0.70 \text { to } 1.56)\end{array}$ & 0.87 & $\begin{array}{l}1.05 \\
(0.82 \text { to } 1.34)\end{array}$ & $\begin{array}{l}1.01 \\
(0.79 \text { to } 1.29)\end{array}$ & $\begin{array}{l}1.06 \\
(0.83 \text { to } 1.34)\end{array}$ & 1043 \\
\hline $\begin{array}{l}\text { Habitual alcohol } \\
\text { drinker }\end{array}$ & $\begin{array}{l}0.96 \\
(0.71 \text { to } 1.31)\end{array}$ & $\begin{array}{l}1.14 \\
(0.84 \text { to } 1.54)\end{array}$ & $\begin{array}{l}1.10 \\
(0.81 \text { to } 1.49)\end{array}$ & $\begin{array}{l}0.89 \\
(0.65 \text { to } 1.22)\end{array}$ & $\begin{array}{l}0.89 \\
(0.65 \text { to } 1.22)\end{array}$ & $\begin{array}{l}1.19 \\
(0.88 \text { to } 1.60)\end{array}$ & $\begin{array}{l}0.83 \\
(0.61 \text { to } 1.14)\end{array}$ & 664 \\
\hline $\begin{array}{l}\text { Not habitual alcohol } \\
\text { drinker }\end{array}$ & $\begin{array}{l}0.89 \\
(0.72 \text { to } 1.09)\end{array}$ & $\begin{array}{l}1.09 \\
(0.89 \text { to } 1.32)\end{array}$ & $\begin{array}{l}0.96 \\
(0.79 \text { to } 1.18)\end{array}$ & $\begin{array}{l}1.00 \\
(0.82 \text { to } 1.22)\end{array}$ & $\begin{array}{l}1.08 \\
(0.89 \text { to } 1.32)\end{array}$ & $\begin{array}{l}0.95 \\
(0.78 \text { to } 1.17)\end{array}$ & $\begin{array}{l}1.06 \\
(0.87 \text { to } 1.30)\end{array}$ & 1559 \\
\hline \multicolumn{9}{|l|}{ Medical history } \\
\hline Diabetes & $\begin{array}{l}0.84 \\
(0.63 \text { to } 1.12)\end{array}$ & $\begin{array}{l}1.07 \\
(0.81 \text { to } 1.42)\end{array}$ & $\begin{array}{l}1.11 \\
(0.84 \text { to } 1.46)\end{array}$ & $\begin{array}{l}1.01 \\
(0.76 \text { to } 1.34)\end{array}$ & $\begin{array}{l}1.11 \\
(0.84 \text { to } 1.46)\end{array}$ & $\begin{array}{l}0.96 \\
(0.72 \text { to } 1.27)\end{array}$ & $\begin{array}{l}0.92 \\
(0.69 \text { to } 1.22)\end{array}$ & 791 \\
\hline No diabetes & $\begin{array}{l}0.95 \\
(0.77 \text { to } 1.16)\end{array}$ & $\begin{array}{l}1.10 \\
(0.90 \text { to } 1.34)\end{array}$ & $\begin{array}{l}0.91 \\
(0.74 \text { to } 1.12)\end{array}$ & $\begin{array}{l}0.98 \\
(0.80 \text { to } 1.20)\end{array}$ & $\begin{array}{l}0.96 \\
(0.79 \text { to } 1.18)\end{array}$ & $\begin{array}{l}1.06 \\
(0.87 \text { to } 1.29)\end{array}$ & $\begin{array}{l}1.02 \\
(0.83 \text { to } 1.24)\end{array}$ & 1534 \\
\hline Hypertension & $\begin{array}{l}1.02 \\
(0.81 \text { to } 1.29)\end{array}$ & $\begin{array}{l}1.17 \\
(0.94 \text { to } 1.47)\end{array}$ & $\begin{array}{l}0.83 \\
(0.65 \text { to } 1.05)\end{array}$ & $\begin{array}{l}0.97 \\
(0.76 \text { to } 1.22)\end{array}$ & $\begin{array}{l}0.97 \\
(0.77 \text { to } 1.23)\end{array}$ & $\begin{array}{l}1.10 \\
(0.88 \text { to } 1.38)\end{array}$ & $\begin{array}{l}0.96 \\
(0.76 \text { to } 1.21)\end{array}$ & 1156 \\
\hline No hypertension & $\begin{array}{l}0.83 \\
(0.65 \text { to } 1.05)\end{array}$ & $\begin{array}{l}1.05 \\
(0.83 \text { to } 1.32)\end{array}$ & $\begin{array}{l}1.15 \\
(0.91 \text { to } 1.44)\end{array}$ & $\begin{array}{l}1.01 \\
(0.80 \text { to } 1.27)\end{array}$ & $\begin{array}{l}1.07 \\
(0.85 \text { to } 1.35)\end{array}$ & $\begin{array}{l}0.95 \\
(0.75 \text { to } 1.20)\end{array}$ & $\begin{array}{l}0.97 \\
(0.76 \text { to } 1.22)\end{array}$ & 1149 \\
\hline Hyperlipidaemia & $\begin{array}{l}0.98 \\
(0.75 \text { to } 1.28)\end{array}$ & $\begin{array}{l}1.05 \\
(0.80 \text { to } 1.36)\end{array}$ & $\begin{array}{l}1.03 \\
(0.79 \text { to } 1.34)\end{array}$ & $\begin{array}{l}0.93 \\
(0.71 \text { to } 1.22)\end{array}$ & $\begin{array}{l}1.17 \\
(0.90 \text { to } 1.52)\end{array}$ & $\begin{array}{l}0.88 \\
(0.67 \text { to } 1.16)\end{array}$ & $\begin{array}{l}0.94 \\
(0.71 \text { to } 1.23)\end{array}$ & 878 \\
\hline No hyperlipidaemia & $\begin{array}{l}0.89 \\
(0.71 \text { to } 1.11)\end{array}$ & $\begin{array}{l}1.11 \\
(0.90 \text { to } 1.37)\end{array}$ & $\begin{array}{l}0.96 \\
(0.77 \text { to } 1.19)\end{array}$ & $\begin{array}{l}1.02 \\
(0.82 \text { to } 1.26)\end{array}$ & $\begin{array}{l}0.93 \\
(0.75 \text { to } 1.15)\end{array}$ & $\begin{array}{l}1.10 \\
(0.89 \text { to } 1.35)\end{array}$ & $\begin{array}{l}1.01 \\
(0.81 \text { to } 1.25)\end{array}$ & 1372 \\
\hline Previous MI & $\begin{array}{l}1.43 \\
(0.94 \text { to } 2.17)\end{array}$ & $\begin{array}{l}1.03 \\
(0.66 \text { to } 1.59)\end{array}$ & $\begin{array}{l}1.10 \\
(0.71 \text { to } 1.70)\end{array}$ & $\begin{array}{l}0.76 \\
(0.47 \text { to } 1.20)\end{array}$ & $\begin{array}{l}0.98 \\
(0.63 \text { to } 1.52)\end{array}$ & $\begin{array}{l}0.78 \\
(0.49 \text { to } 1.24)\end{array}$ & $\begin{array}{l}0.90 \\
(0.57 \text { to } 1.41)\end{array}$ & 317 \\
\hline No previous $\mathrm{Ml}$ & $\begin{array}{l}0.83 \\
(0.69 \text { to } 1.00)\end{array}$ & $\begin{array}{l}1.09 \\
\text { (0.92 to } 1.31)\end{array}$ & $\begin{array}{l}0.98 \\
(0.81 \text { to } 1.17)\end{array}$ & $\begin{array}{l}1.00 \\
(0.84 \text { to } 1.20)\end{array}$ & $\begin{array}{l}1.04 \\
(0.87 \text { to } 1.25)\end{array}$ & $\begin{array}{l}1.06 \\
(0.89 \text { to } 1.27)\end{array}$ & $\begin{array}{l}1.00 \\
(0.84 \text { to } 1.20)\end{array}$ & 1934 \\
\hline Previous angina & $\begin{array}{l}0.91 \\
(0.66 \text { to } 1.25)\end{array}$ & $\begin{array}{l}1.01 \\
(0.74 \text { to } 1.39)\end{array}$ & $\begin{array}{l}0.87 \\
(0.63 \text { to } 1.21)\end{array}$ & $\begin{array}{l}1.05 \\
(0.77 \text { to } 1.44)\end{array}$ & $\begin{array}{l}1.09 \\
(0.80 \text { to } 1.49)\end{array}$ & $\begin{array}{l}1.14 \\
(0.84 \text { to } 1.56)\end{array}$ & $\begin{array}{l}0.95 \\
(0.69 \text { to } 1.30)\end{array}$ & 638 \\
\hline No previous angina & $\begin{array}{l}0.90 \\
(0.74 \text { to } 1.11)\end{array}$ & $\begin{array}{l}1.15 \\
(0.95 \text { to } 1.40)\end{array}$ & $\begin{array}{l}1.05 \\
(0.86 \text { to } 1.28)\end{array}$ & $\begin{array}{l}0.970 \\
(0.79 \text { to } 1.18)\end{array}$ & $\begin{array}{l}1.01 \\
(0.82 \text { to } 1.23)\end{array}$ & $\begin{array}{l}0.99 \\
(0.81 \text { to } 1.20)\end{array}$ & $\begin{array}{l}0.97 \\
(0.79 \text { to } 1.18)\end{array}$ & 1594 \\
\hline \multicolumn{9}{|l|}{ Infarct characteristics } \\
\hline Q wave infarct & $\begin{array}{l}0.93 \\
(0.76 \text { to } 1.12)\end{array}$ & $\begin{array}{l}1.11 \\
(0.92 \text { to } 1.34)\end{array}$ & $\begin{array}{l}0.97 \\
(0.80 \text { to } 1.17)\end{array}$ & $\begin{array}{l}1.01 \\
(0.83 \text { to } 1.22)\end{array}$ & $\begin{array}{l}1.05 \\
(0.87 \text { to } 1.27)\end{array}$ & $\begin{array}{l}0.94 \\
(0.77 \text { to } 1.14)\end{array}$ & $\begin{array}{l}1.02 \\
(0.85 \text { to } 1.24)\end{array}$ & 1726 \\
\hline Non- $Q$ wave infarction & $\begin{array}{l}0.93 \\
(0.66 \text { to } 1.30)\end{array}$ & $\begin{array}{l}1.15 \\
(0.83 \text { to } 1.59)\end{array}$ & $\begin{array}{l}0.99 \\
(0.71 \text { to } 1.38)\end{array}$ & $\begin{array}{l}0.83 \\
(0.59 \text { to } 1.17)\end{array}$ & $\begin{array}{l}0.99 \\
(0.70 \text { to } 1.38)\end{array}$ & $\begin{array}{l}1.23 \\
(0.89 \text { to } 1.69)\end{array}$ & $\begin{array}{l}0.91 \\
(0.65 \text { to } 1.28)\end{array}$ & 560 \\
\hline Anterior infarct & $\begin{array}{l}0.93 \\
(0.74 \text { to } 1.18)\end{array}$ & $\begin{array}{l}1.04 \\
(0.83 \text { to } 1.31)\end{array}$ & $\begin{array}{l}0.95 \\
(0.75 \text { to } 1.20)\end{array}$ & $\begin{array}{l}0.99 \\
(0.79 \text { to } 1.25)\end{array}$ & $\begin{array}{l}1.04 \\
(0.82 \text { to } 1.30)\end{array}$ & $\begin{array}{l}1.01 \\
(0.81 \text { to } 1.28)\end{array}$ & $\begin{array}{l}1.04 \\
(0.82 \text { to } 1.30)\end{array}$ & 1169 \\
\hline Not anterior infarct & $\begin{array}{l}0.86 \\
(0.67 \text { to } 1.10)\end{array}$ & $\begin{array}{l}1.15 \\
(0.91 \text { to } 1.45)\end{array}$ & $\begin{array}{l}1.04 \\
(0.82 \text { to } 1.32)\end{array}$ & $\begin{array}{l}1.00 \\
(0.79 \text { to } 1.27)\end{array}$ & $\begin{array}{l}0.99 \\
(0.78 \text { to } 1.26)\end{array}$ & $\begin{array}{l}1.01 \\
(0.79 \text { to } 1.28)\end{array}$ & $\begin{array}{l}0.92 \\
(0.72 \text { to } 1.17)\end{array}$ & 1086 \\
\hline Multivessel disease $\ddagger$ & $\begin{array}{l}0.99 \\
(0.94 \text { to } 1.35)\end{array}$ & $\begin{array}{l}1.12 \\
(0.82 \text { to } 1.52)\end{array}$ & $\begin{array}{l}1.10 \\
(0.81 \text { to } 1.50)\end{array}$ & $\begin{array}{l}0.98 \\
(0.71 \text { to } 1.33)\end{array}$ & $\begin{array}{l}0.94 \\
(0.68 \text { to } 1.29)\end{array}$ & $\begin{array}{l}0.94 \\
(0.68 \text { to } 1.29)\end{array}$ & $\begin{array}{l}0.91 \\
(0.66 \text { to } 1.25)\end{array}$ & 641 \\
\hline Single vessel disease $\ddagger$ & $\begin{array}{l}0.84 \\
(0.68 \text { to } 1.04)\end{array}$ & $\begin{array}{l}1.07 \\
(0.87 \text { to } 1.31)\end{array}$ & $\begin{array}{l}0.97 \\
(0.79 \text { to } 1.19)\end{array}$ & $\begin{array}{l}1.04 \\
(0.85 \text { to } 1.27)\end{array}$ & $\begin{array}{l}1.09 \\
(0.89 \text { to } 1.34)\end{array}$ & $\begin{array}{l}1.03 \\
(0.84 \text { to } 1.27)\end{array}$ & $\begin{array}{l}1.01 \\
(0.82 \text { to } 1.23)\end{array}$ & 1505 \\
\hline
\end{tabular}

by sociodemographic variables, medical history, and infarct characteristics (table 2). No significant variation in onset was observed in stratified subgroups of patients categorised with respect to age, known cardiac risk factors, previous myocardial infarction, previous angina, and infarct characteristics. However, there were pronounced differences in groups of patients where myocardial infarction was classified by sex (fig 2) and by working status (fig 3 ).
In 604 women, there was a prominent Saturday peak in the onset of infarction, with a 39\% increase in relative risk (odds ratio $1.39,95 \%$ confidence interval (CI) 1.02 to 1.88 ; $\mathrm{p}=0.037$ ) compared with the expected number of cases if homogeneity was assumed (fig 2A). In 1796 men, the distribution was fairly uniform ( fig 2B).

In 1247 working patients, there was a Monday peak in the onset of infarction, with a $26 \%$ increase in relative risk (odds 

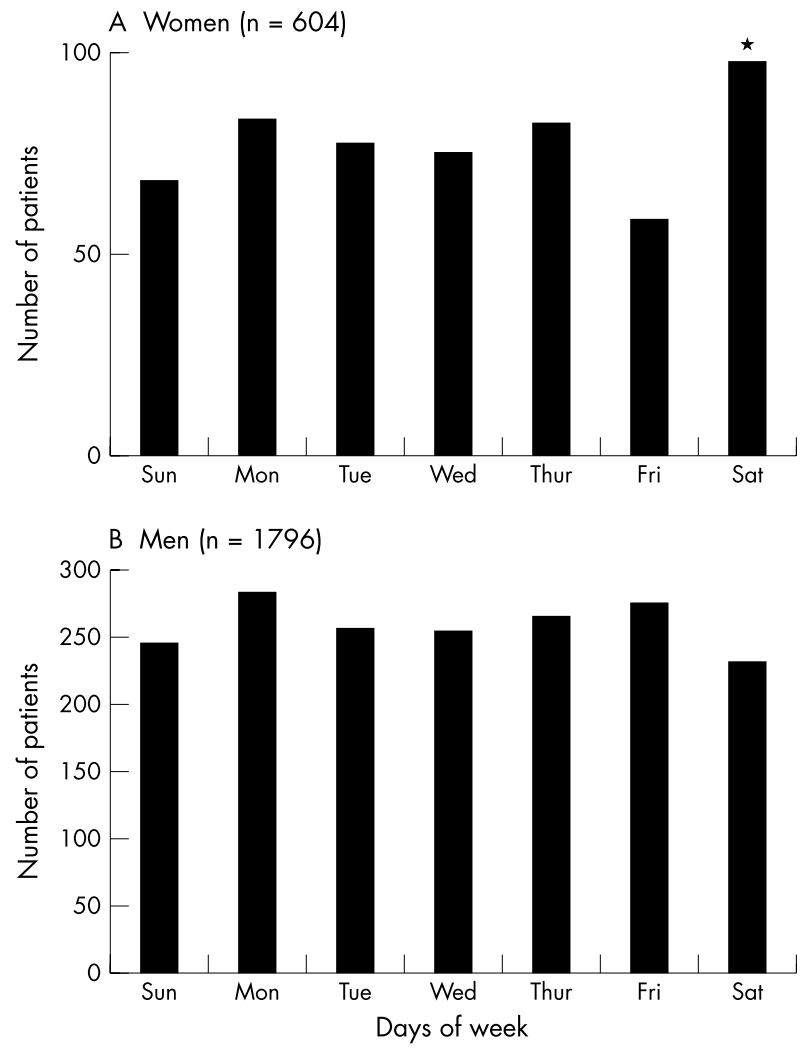

Figure 2 Day of the week of acute myocardial infarction in women (panel $A, n=604$ ) and in men (panel $B, n=1796$ ). The Mantel-Haenszel test indicated a Saturday peak in women, with a $39 \%$ increase in relative risk (odds ratio $1.39,95 \% \mathrm{Cl} 1.02$ to 1.88 ; $p=0.037$ ), as opposed to men, who had a more even distribution.

ratio $1.26,95 \%$ CI 1.01 to $1.56 ; \mathrm{p}=0.038$ ) compared with the expected with number of cases if homogeneity was assumed (fig 3A). In 1038 non-working patients, no variation through the week was observed (fig 3B). As the significant peak in the onset of infarction was found in women and in working subjects, stratified analyses might differentiate further between working versus non-working men and working versus non-working women.

Figure 4 shows the day of the week of acute myocardial infarction in working and non-working men. In 1124 working men, there was a Monday peak of onset, with a $30 \%$ increase in relative risk (odds ratio $1.30,95 \%$ CI 1.04 to $1.64 ; p=0.022$ ) compared with the expected number of cases if homogeneity was assumed (fig 4A). In 558 non-working men, the distribution was fairly uniform (fig 4B).

Figure 5 shows the day of the week of onset of myocardial infarction in working women and non-working women. In 123 working women, the distribution of the day of onset during the week showed no significant variation. In 450 non-working women, there was a peak in the number of patients with infarction occurring on Saturday, although this did not reach significance.

\section{DISCUSSION}

In our study population as a whole we found no variation in the onset of acute myocardial infarction with respect to the day of the week in patients in the Osaka area. However, in subgroup analyses, women showed a Saturday peak, while working subjects showed a Monday peak. Stratified analyses showed that in working men there was a Monday peak in the onset of infarction, while in working women the distribution of the day of onset showed no significant variation through the week.
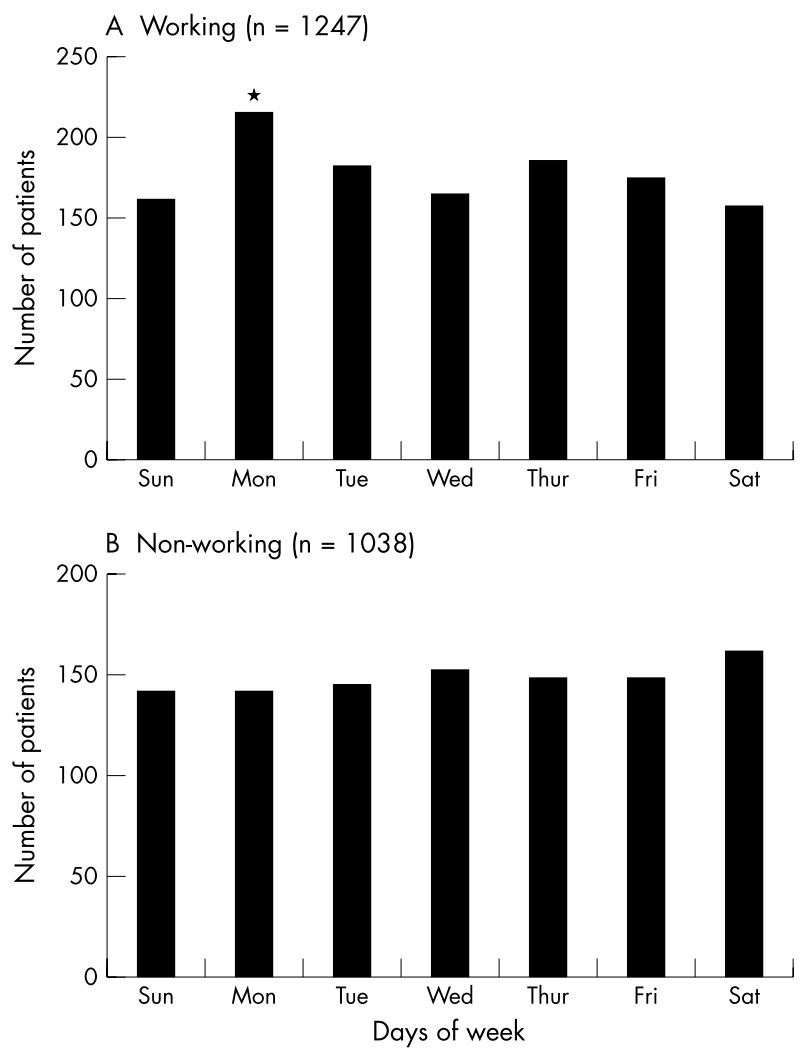

Figure 3 Day of the week of acute myocardial infarction in working subjects (panel $A, n=1247$ ) and non-working subjects (panel $B, n=1038$ ). The occurrence of infarction shows a Monday peak in working subjects, with a $26 \%$ increase in relative risk lodds ratio $1.26,95 \% \mathrm{Cl} 1.01$ to $1.56 ; \mathrm{p}=0.038$ ), as opposed to the non-working subjects, who had a more even distribution.

Previous studies on the weekly distribution of cardiac events have consistently suggested an increase risk on Monday, ${ }^{1-5}$ while a few reports have indicated a peak on other days of week or none at all. ${ }^{67}$ Willich and colleagues attributed the Monday peak to resumption of work stress, as the effect was not seen in the non-working population. ${ }^{3}$ Our working patients also showed a Monday peak, although the study population overall did not. As most of our female subjects were not employed, their patterns which included a Saturday peak obscured the Monday peak among our subjects as a whole.

The observation of a Monday peak of acute myocardial infarction in working individuals is of particular interest as it is compatible with the hypothesis that external triggering factors play a role in the sudden onset of infarction. Although detailed information on the working schedules of our study subjects was not obtained, it is reasonable to assume that there was an increase in physical and mental burden on Mondays after the weekend in the majority of working patients. The speculation that there is an association between work burden and disease onset is indirectly supported by several cohort studies. ${ }^{18}$ The weekly variation in time of onset seen in the working population suggests that external stimuli are important. Further investigation of the weekly distribution of myocardial infarction in relation to the type of work done and variations in work schedules may provide further insight into the relation between activities and cardiovascular risk.

Our study also showed that there was a prominent Saturday peak in disease onset in women. To our knowledge, this has not been reported before. A significant peak on Saturday in women implies the involvement of a triggering factor. As physical and mental stresses were not examined in this study, we can only speculate on the possible stresses attributable to 

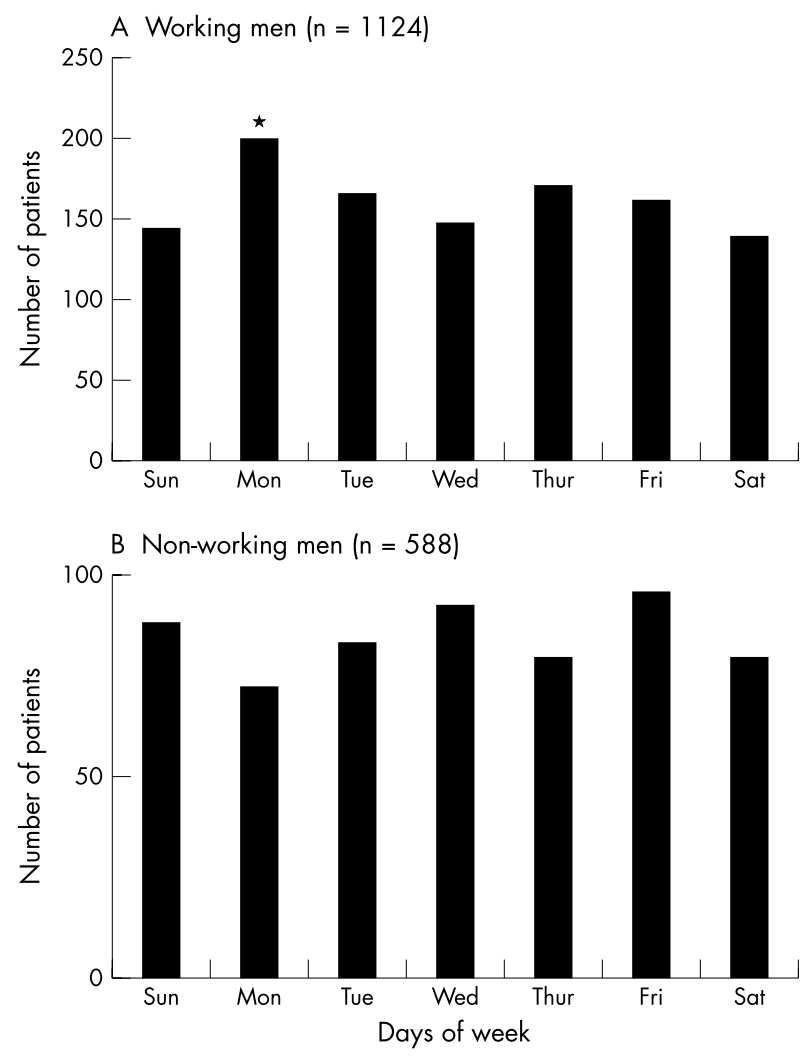

Figure 4 Day of the week of onset of acute myocardial infarction in working men (panel $A, n=1124$ ) and non-working men (panel $B$, $n=588$ ). There was a Monday peak in the occurrence of infarction in working men, with $30 \%$ increase in relative risk (odds ratio 1.30 , $95 \% \mathrm{Cl} 1.04$ to $1.64 ; \mathrm{p}=0.022$ ), as opposed to non-working men, who had a more even distribution.

the Saturday peak. However, it has been reported that there is an increase in the level of stress and frustration at weekends in women with weekend headache. ${ }^{14}$ Thus it is possible that there may be an increase in the physical and mental burden for women on Saturday following less stressful weekday activities in certain cultural backgrounds. Most housewives in Japan take full responsibility for housekeeping duties, not only on weekdays but also at weekends, in line with Confucian ethics and the patriarchism inherent in the Far East. Thus there is an increase in their work burden at weekends, which may be implicated in the increased risk of acute myocardial infarction on Saturdays. Further investigation into the weekly distribution of acute myocardial infarction in patients from different cultural backgrounds, especially in the Far East, may provide additional insights into the relations between social factors and cardiovascular risk.

If weekend stress is important in women, the question arises as to why a Sunday peak was not also observed in our study. The situation may be similar to the Monday peak in the working population. Although there is likely to be increased stress over the whole weekend, the abrupt increase in physical and mental burden on Saturdays following less stressful weekday activities may generate the single Saturday peak.

In the light of the above findings, it was of particular interest to determine whether any peaks in the onset of acute myocardial infarction occurred in subgroups of working men, non-working men, working women, and non-working women. In working men, there was a Monday peak, as described, while in non-working men the distribution was fairly uniform. It is to be expected that an increase in physical and mental burden on Monday is an important potential trigger of acute myocardial infarction in working men. On the other hand, working women did not show this effect, and they
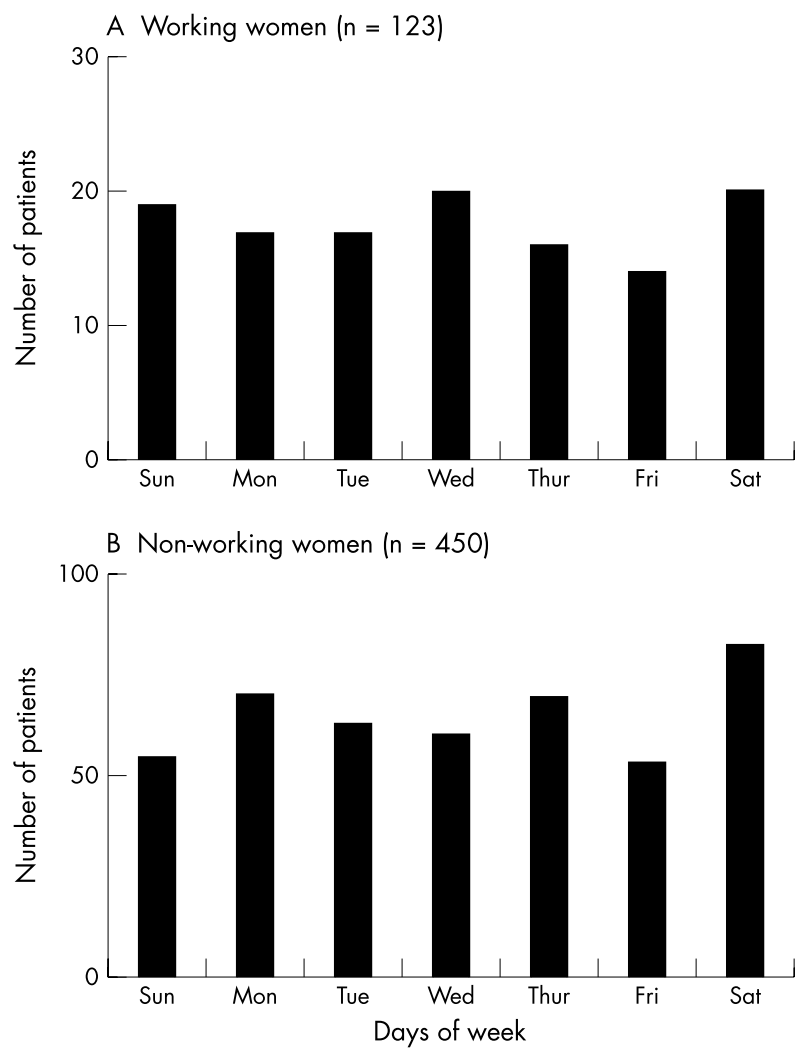

Figure 5 Day of the week of onset of acute myocardial infarction in working women (panel $A, n=123$ ) and non-working women (panel $B, n=450$ ). There was no significant variation through the week in working women. In non-working women, there was a peak in the number of patients with infarction occurring on Saturday, although this did not reach significance.

had an even weekly distribution of disease onset. One possible explanation for this is that working women in Japan still have to perform the chores traditionally reserved for housewives, so their full time job is added to their housekeeping duties. It is expected that stress and frustration will be present throughout the week and the weekend in working women in Japan, so peaks on Mondays or Saturdays are likely to be blunted. However, the annual incidence of acute myocardial infarction seems to be extremely low among working women, so a nationwide study with larger numbers is needed to confirm this result statistically.

\section{Study limitations and conclusions}

One possible limitation of our study involves the sampling technique, which was based on a patient's admission for acute myocardial infarction to a collaborating hospital in the Osaka area. A cohort study design would have strengthened the results, as not all patients with acute myocardial infarction in the Osaka area were registered as study subjects. However, more than one third of the patients with acute myocardial infarction in Osaka appear to be registered at the participating hospitals, which are distributed throughout the Osaka area. ${ }^{15}$ Thus bias related to patient numbers or uneven geographical distribution was probably minimal. However, a larger study would provide a improved statistical power in the subgroup analyses.

There may also be reporting bias. It is possible that women may be deterred from going to hospital with chest pain because of their family responsibilities. This view is supported by the observation that the number of female patients was smallest on Fridays. However, as the delay between the onset of symptoms and the time of hospital admission did not differ 
among the days of week in this study (data not shown), such reporting bias is likely to be small. Moreover, classification of infarction onset by day of the week reflected the time of the onset of the symptoms and not the time of arrival at hospital.

Another limitation involves the lack of precise information about the work schedules of the patients, though it is highly likely that there was an increase in stress upon return to work on Monday. Stress factors in Japanese women are less clear, although increases of stressful events during weekends have been cited and could be involved in triggering myocardial infarction.

Whatever the specific mechanisms, our results support the view that the increased physical and mental burden on Mondays acts as a trigger for acute myocardial infarction in workers, while undetermined factors, possibly related to stressful lifestyles, result in a Saturday peak in Japanese women. A more detailed assessment of activity patterns and cultural factors that could determine the onset of myocardial infarction is needed.

\section{ACKNOWLEDGEMENTS}

We thank Kumiko Miyoshi, Chizuru Hamaguchi, Hiroko Machida, Mariko Yoneda, Ayako Okamoto, and Kana Sakatani for their excellent assistance with data collection. This study was supported by a grant-in-aid for University and Society Collaboration (No 11794035) from the Japanese Ministry of Education, Culture, Sports, Science, and Technology, Tokyo, Japan, and by a research grant from the Japan Arteriosclerosis Prevention Fund.

\section{APPENDIX}

The following persons and institutions participated in the OACIS: Sakurabashi Watanabe Hospital, Osaka: K Fujii, H Ito; Osaka Police Hospital, Osaka: K Kodama, A Hirayama; Kansai Rosai Hospital, Amagasaki: S Nagata, S Nanto, T Morozumi; Osaka Prefectural General Hospital, Osaka: N Hoki, M Fukunami, T Shimonagata; Ishinkai Yao General Hospital, Yao: Y Matsu-ura, Y Kato; Osaka National Hospital, Osaka: T Hayashi, H Kusuoka, Y Koretsune; Higashi-Osaka City General Hospital, HigashiOsaka: Y Kijima, S Ike; Osaka Rosai Hospital, Sakai: Y Yamada, J Tanouchi, S Hoshida; Kawachi General Hospital, Higashi-Osaka: M Mishima, Y J Lim; Osaka Minami National Hospital, Kawachinagano: N Kinoshita, M Naka, K Imai; Osaka Kosei Nenkin Hospital, Osaka: T Sasaki; Osaka Railway Hospital of West Japan Railway Company, Osaka: Y Abe, A Ezumi; Yao Municipal Hospital, Yao: A Kohama, K Umemoto; Kaizuka City Hospital, Kaizuka: H Morita, JM Lee; Kita-Osaka Hospital, Osaka: N Ogitani, K Otani; Setsu Iseikai Hospital, Setsu: N Akehi; Kobe Ekisaikai Hospital, Kobe: T Shimazu, H Fuji; Kashiwara City Hospital, Kashiwara: S Fukui, T Akashi; Teramoto Memorial Hospital, Kawachinagano: E Hishida; Shinsenri Hospital, Osaka: Y Misaki; Meiwa Hospital, Nishinomiya: M Sugii; Osaka Dai-Ichi Hospital, Osaka: T Ohara; Osaka Kaisei Hospital, Osaka: Y Katsube; Osaka Seamens Insurance Hospital, Osaka: M Uematsu; Department of Internal Medicine and Therapeutics, Osaka University Graduate School of Medicine, Suita: T Masuyama, K Otsu, K Yamamoto; Department of Medical Information Science, Osaka University Graduate School of Medicine, Suita: Y Matsumura.

\section{Authors' affiliations}

K Kinjo, Hiroshi Sato, Hideyuki Sato, I Shiotani, E Hishida,

D Nakatani, H Mizuno, M Hori, Department of Internal Medicine and Therapeutics, Osaka University Graduate School of Medicine, Suita, Japan

T Kurotobi, Osaka Police Hospital, Osaka, Japan

Y Ohnishi, Laboratory for Cardiovascular Diseases, SNP Research Centre, The Institute of Physical and Chemical Research (RIKEN), Tokyo, Japan

Y Yamada, Osaka Rosai Hospital, Sakai, Japan

S Fukui, Kashiwara City Hospital, Kashiwara, Japan

M Fukunami, Osaka Prefectural General Hospital, Osaka, Japan

S Nanto, Kansai Rosai Hospital, Amagasaki, Japan

Y Matsu-ura, Ishinkai Yao General Hospital, Yao, Japan

H Takeda, Department of Medical Information Science, Osaka

University Graduate School of Medicine, Suita, Japan

\section{REFERENCES}

1 Thompson D, Pohl J, Sutton T. Acute myocardial infarction and day of the week. Am J Cardiol 1992;69:266-7.

2 Gnecchi-Ruscone T, Piccaluga E, Guzzetti S, et al. Morning and Monday: critical periods for the onset of acute myocardial infarction. Eur Heart J 1994;15:882-7

3 Willich S, Lowel $\mathrm{H}$, Lewis $M$, et al. Weekly variation of acute myocardial infarction: Increased Monday risk in the working population. Circulation 1994;90:87-93.

4 Massing W, Angermeyer M. Myocardial infarction on various days of the week. Psychol Med 1985;15:851-7.

5 Spielberg C, Falkenhahn D, Willich SN, et al. Circadian, day-of-week, and seasonal variability in myocardial infarction: comparison between working and retired patients. Am Heart J 1996;132:579-85.

6 Sayer J, Wiikinson P, Ranjadayalan K, et al. Attention or absence of circadian and seasonal rhythms of acute myocardial infarction. Heart 1997:77:325-9.

7 Chiang $\mathbf{H}$, Lin S, Ku C, et al. Circadian and weekly variations in pain onset of acute myocardial infarction. Zhonghua Yi Xue Za Zhi (Taipei) 1999;62:334-40.

8 Muller J, Tofler G, Stone P. Circadian variation and triggers of onset of acute cardiovascular disease. Circulation 1989;79:733-43.

9 Freedman SB, Wong CK. Triggers of daily life ischaemia. Heart 1998;80:489-92.

10 Moller J, Ahlbom A, Hulting J, et al. Sexual activity as a trigger of myocardial infarction. A case-crossover analysis in the Stockholm Heart Epidemiology Programme (SHEEP). Heart 2001;86:387-90.

11 Trichopoulos D, Katsouyanni K, Zavitsanos X, et al. Psychological stress and fatal heart attack: the Athens (1981) earthquake natural experiment. Lancet 1983;i:441-4.

12 Glass RI, Zack MM. Increase in deaths from ischaemic heart-disease after blizzards. Lancet 1979; i:485-7.

13 Meisel SR, Kutz I, Dayan KI, et al. Effect of Iraqi missile war on incidence of acute myocardial infarction and sudden death in Israeli civilians. Lancet 1991;338:660-1.

14 Torelli P, Cologno D, Manzoni GC. Weekend headache: a possible role of work and life-style. Headache 1999;39:398-408.

15 Kinjo K, Sato H, Sato H, et al. Circadian variation of the onset of acute myocardial infarction in the Osaka area, 1998-1999: characterization of morning and nighttime peaks. Jpn Circ J 2001;65:617-20.

16 Ohnishi Y, Tanaka T, Yamada R, et al. Identification of 187 single nucleotide polymorphisms (SNPs) among 41 candidate genes for ischemic heart disease in the Japanese population. Hum Genet 2000; 106:288-92

17 Mantel N, Haenszel W. Statistical aspects of the analysis of data from retrospective studies of diseases. I Natl Cancer Inst 1959:22:719-48.

18 Tuchsen F. Working hours and ischaemic heart disease in Danish men: a 4 -year cohort study of hospitalization. Int J Epidemiol 1993;22:215-21. 